\title{
COUNTER THE COUNTERSTORY
}

NARRATIVE APPROACHES TO NARRATIVES

\author{
Hilde Lindemann
}

\begin{abstract}
COUnterstory, as I have developed the concept, is a story that is told for the purpose of resisting a socially shared narrative used to justify the oppression of a social group. ${ }^{1}$ The socially shared story enters the tissue of stories that constitute the group's identity, damaging that identity and thereby constricting group members' access to the goods on offer in their society. The counterstory sets out to uproot some part of the oppressive story and replace it with a more accurate one. In this way it can sometimes repair the damage to the identity. Whether it succeeds is a question of uptake: enough people in the dominant group must accept the new story and treat the members of the group accordingly.

In this paper, I explore some of the difficulties that arise in getting a counterstory to succeed. I will focus in particular on six narrative strategies that people in dominant social positions use to counter a counterstory and thereby keep an oppressive social order in place, and then I will offer a tiny hope. But first I will have to say a little more about how personal identities work.
\end{abstract}

\section{THE SOCIAL PRACTICE OF PERSONAL IDENTITIES}

What I have called the social practice of personal identities is a moral practice we engage in constantly, but it has not received much recognition as a moral practice: it is the practice of initiating human beings into personhood and then holding them there. I argue that personhood consists of four necessary elements: (1) a human being has sufficient mental activity to constitute a personality; (2) aspects of this personality are expressed bodily; (3) other persons recognize it as the expression of a personality; and (4) they respond to what they see. Recognition and response are often a matter of understanding who someone is and interacting with them on that basis.

These understandings - both the self-conception we express and the recog-

1 Lindemann, Damaged Identities, Narrative Repair. 
nition that is others' sense of who we are-consist of a web of stories depicting our most important acts, experiences, characteristics, roles, relationships, and commitments. Some of the stories are personal (I grew up in a German-speaking household), while others are widely circulated stories we use to make sense of the social groups to which we belong - white, middle-class women, university professors, mothers, and so on (I am all of the above). This narrative tissue constitutes our personal identities, which play a crucial role in the practice of personhood.

Our personal identities fuel the practice because they indicate who we are with respect to other persons and in that way guide not only how we are supposed to treat those others, but also how we are supposed to conduct ourselves. As the practice of personhood is governed by rules that are both socially and morally normative, my description of how we engage in the practice aims to capture something important about how morality — an interpersonal practicefunctions.

We are initiated into personhood though interactions with other persons, and we both develop and maintain personal identities through interactions with others who hold us in our identities, as we hold them in theirs. ${ }^{2}$ This holding can be done well or badly. Done well, it supports an individual in the creation and maintenance of a personal identity that allows her to flourish personally and in her interactions with others. Done badly, we hold people in invidious, destructive narratives. In some cases, the damaging narratives identify the social group to which someone belongs as socially and morally inferior and in that way uphold abusive power relations between "us" and "them." In other cases, the stories that purport to represent the individual's acts or experiences or other important personal characteristics are flat-out false or get the proportions wrong. In this paper, though, I am going to set the flawed depictions of individuals to one side and focus on the stories that damage the identities of the social groups to which the individuals belong.

\section{OPPRESSIVE MASTER NARRATIVES}

For convenience, let us call the socially shared stories that everybody knows the master narratives of that society. Many fairy tales qualify as master narrativesthink of "Snow White" or "Goldilocks and the Three Bears"-and so do nursery rhymes such as "Humpty Dumpty." Children's books such as the Harry Potter series and the Shakespearean plays Hamlet and Macbeth count too. So do the biblical tales of Adam and Eve, Samson and Delilah, and the Prodigal Son.

Master narratives are crucial for any social interaction, because they depict 
how we are supposed to behave in specific settings. The school narrative tells you that students should sit in their desks and raise their hand for permission to speak but that the teacher may speak and move about freely. The restaurant narrative tells you that when you finish your meal, you must not leave without paying.

Master narratives like these that guide us through life are often reasonably benign, but there are some whose dictates serve to reinforce unjust distributions of social power by pretending to justify them. They do it by depicting certain groups of people- "them"-as inferior to "us." Jews are money-loving self-promoters. Brown-skinned people are dirty and dangerous. Women are stupid sluts. And so on. The trouble is, when a group of people is stereotyped in that way, the people doing the stereotyping find it normal and natural to treat members of the group accordingly. That puts restrictions on how the group members can act. In the United States, for instance, if you are a man with brown skin, the likelihood that you will be killed by the police is three times greater than if you are white. ${ }^{3}$ If you are a young black man, the odds go up to twenty-one times greater. ${ }^{4}$ If you are a woman, the chances are one in four that you will be raped during your lifetime. In both cases, the stories that masquerade as an explanation for why you deserve that sort of treatment are so powerful that even when we know they are false, they still retain some of their hold over us. One way this works is that master narratives do not essentialize, but tolerate exceptions, and that adds to their durability. One can continue to believe the narrative because the cases where one can see plainly that it is false can be explained away as an aberration: "Well, yeah, she didn't dress like a slut, but most girls do." "Oh, he's different-he's a credit to his race."

Where does their power come from? What is it about damaging master narratives that makes them so much like dragons devouring everything in their path? First, they are organic ensembles of stories that grow and change. Second, they constitute a world view. Third, they are epistemically rigged. And fourth, because of these three features, they are very good at assimilating opposition.

\subsection{Organic Ensembles}

Let us take these features in order. As is perhaps apparent by now, talk of $a$ master narrative is really just a manner of speaking, because the term does not designate a single story with a specific plot and a fixed cast of characters. Instead, they are ensembles of repeated themes that take on a life of their own. Fragments of

3 Sikora and Mulvihill, "Trends in Mortality Due to Legal Intervention in the United States, 1979 through 1997."

4 National Public Radio, "ProPublica Analyzes 3 Decades of Deadly Police Shootings." 
history, biography, film, fables, jokes, and similar narrative forms ring changes on the theme, as do proverbs, music, advertising slogans, and other cultural artifacts. Master narratives are capacious, as cluttered and untidy as a Victorian attic, but unlike the attic, they grow or shrink over time. An altered political economy or other social change can push a master narrative in a new direction. What moves it along are additional images, stories, songs, and slogans.

Take the story of Cinderella, whose only hope of a good life is for a powerful man to recognize her sexual appeal, marry her, and carry her off to his castle. This got an update in 1990 in the movie Pretty Woman, which highlights women's identity as a slut-Julia Roberts plays a sex worker-but her sexual appeal is strong enough to persuade the rich and handsome character played by Richard Gere to marry her anyway. Why? Because she demonstrates that she is just as good at serving others without complaint, in her own way, as her original was at looking after her stepmother and stepsisters, which connects her to all the other stories you know about women whose sluttishness can be forgiven as long as they know their place: subservient to men.

Master narratives take on a fresh vigor with each new accretion, but they are also strengthened by their ties to other master narratives. The master narratives depicting brown-skinned people as dirty purport to justify giving them the dirty work: somebody has to collect the trash and mop the floors, and it is fitting that brown men are the ones to do it. As for brown women, well, since they are sluts and servants, but also fit only for dirty work, their job is to serve white people by cleaning their toilets or changing their children's diapers. By interlocking in these ways, master narratives reinforce one another. Because they can incorporate an enormous diversity of even the humblest items in the cultural store, and because they can link themselves to any number of other master narratives that do the same thing, master narratives infiltrate every corner of society.

\subsection{Worldview}

Precisely because they are so widely known, the master narratives of a society allow its members to understand who they are with respect to that society, as well as how the world works. They create a picture of the world that is both comprehensive and reasonably unified because the narratives that constitute them are not only far-reaching but also mutually reinforcing. A theme-say, that women are to serve men-plays itself out not only in the Cinderella and domestic worker narratives but in the master narrative of modern science, which characterizes nature as the feminine Gaia and reason as the masculine figure in a white lab coat who dominates her. You also see it in the narratives that feminize "lower" races, the ones that prescribe what categories of men may have sexual access to what 
categories of women, and the countless advertisements that equate feminine beauty with heterosexual sexiness. One master narrative thus confirms another, and the interlocking, intertwining web of these narratives creates a plausible worldview.

In that narrative web of our beliefs, some of the stories depend on other stories. Those that lie farthest out on the periphery can be given up without much damage to the overall structure, but the closer the story is to the center, the more it supports. Tear out one strand there and a great deal of the web will have to be rebuilt. But since the stories at the center of the web are taken deeply for granted, they are hard to dislodge even when there is evidence that calls them into question, since the evidence can be dismissed as an exception. Even the oppressed, who have every reason to repudiate them, can find it hard to shift them. A master narrative that depicts their group as unworthy or morally subpar can infiltrate the consciousness of some members of the group, causing them to see themselves in the hateful light the story sheds on them. For them, dislodging the story would require calling their own identities into question. Then too, to the extent that group members share the dominant culture's worldview, they have an interest in keeping that narrative web intact. What is at stake is nothing less than their society's - and their own — understanding of life and their place in the universe.

\subsection{Epistemic Rigging}

The third thing that makes damaging master narratives so hard to contest is that they are rigged to make it seem as if nothing bad is going on. Life is much more comfortable for the dominant class if its members can think of their society as just and good. It is hard to do that if subjugated or excluded classes are continually rebelling, and the use of whips and chains to keep them down is just not very efficient. Much better to deal with resistance by stopping it before it starts. And that calls for stories that hide the coercive power circulating through society so that it is not visible unless you look closely. If you can make the justification for keeping those people in their place seem really plausible, the resulting master narrative will be so smooth and slippery that the opposition cannot grab hold of it.

One way to hide the coercion is to naturalize it-to make it seem inevitable that certain classes of people must occupy subordinate positions, or obvious why they have no place in decent society at all. An excellent way to do this is to link the identity to some feature the person was born with, such as a vagina or skin color, because then it appears as if the person's identity came into the world with her, due to some straightforward biological fact about her. The identity does not look as if it was socially constructed at all. No indeed. It was God-given. 
If you cannot rig the master narrative by linking the identity to a trait the group member was born with, you might try privatizing it. Take disability, for example. Most people with disabilities were not born with them-they acquire them later in life. The easiest thing then is to hide them away in nursing homes, or refuse to make the accommodations that allow them to participate in society. You can build your cities with plenty of curbs and steps that cannot be navigated in wheelchairs, force people who are hearing impaired to hire their own interpreters who know sign language, and require blind people to pass the same written exams as everyone else. As for gays and lesbians, just closet them so you do not have to think about what they are doing in there.

If these tactics fail, you can always normalize the identity. This is done when the norms that are supposed to regulate certain kinds of behavior in fact create the identity. Women's identities are normalized by imposing norms of conduct on them that deflect attention away from how they are treated. It is all too common to criticize rape victims for what they were wearing when the rape occurred, or being in a part of town that left them open to attack. Easy, too, to blame the rape on the fact that the victim was drunk at the time, or high on recreational drugs. And if dark skin is supposed to be a badge of subservience, you can be indignant at the person's insubordination without having to stop and wonder why dark-skinned people have to be subordinate.

\section{COUNTERING THE COUNTERSTORY}

If I am right about all this (and I bet I am), it is pretty obvious that counterstories have their work cut out for them. The master narratives they go after are so interconnected, so deeply rooted in our psyches, and so smooth and slippery that the counterstory mostly just bounces off and rolls away harmlessly. And if it cannot get inside the narrative to repair the tissue that is damaging the identity, the people bearing the identity remain unable to move about freely within their society. But let us suppose that the counterstory manages to engage with the master narrative rather than being deflected. At that point the counterstory still faces a huge obstacle, namely, master narratives' ability to assimilate opposition. In what is left of this paper, I am going to describe six ways these narratives absorb opposition, thereby retaining their power and continuing to inflict damage.

\subsection{Make the Language Pretty}

Counterstories protesting violence against members of a subgroup can be tweaked so that they represent what happened in language that is more comfortable for the oppressor. Domestic assaults, committed far more often and more 
violently by men on women than the other way around, become written up in the New York Times as "domestic disputes," which simultaneously erases the violence and makes it appear that both parties contributed equally to a disagreement. "Racial unrest" is a euphemism that hides both the violent behavior of the subgroup protesting its oppression and the violence used by police or other servants of the oppressive social order to beat the subgroup back into submission. "Some of my best friends are Jews" or "I never think of you as black; to me, you're just human" are pretty sentiments that deny the power differential between the speaker and the subgroup, thereby making the subgroup's counterstories seem to be beside the point, or inaptly targeted. Recently I heard someone dismiss sexual harassment as "romantic entanglements," which erases not only the power hierarchy between predator and prey, but also diverts attention from the sense of entitlement that accompanies unwanted sexual groping. Attractive commercials that depict elderly people as retaining their (white) beauty and vigor well into the "golden years," where they play golf and tennis at exclusive country clubs, or walk hand in hand on sunset beaches, do not just paper over the very real indignities of old age's diminishing physical and social power, but make it impossible for counterstories that destigmatize vulnerability and dependence to get heard at all.

\subsection{Play Devil's Advocate}

Here is a second way to counter a counterstory. Let us take the master narratives about lazy, shiftless poor people that arguably fuel the Trump administration's cutbacks in federal spending. Suppose a group of friends is discussing these cutbacks and, by way of a counterstory, someone points out that many people living below the poverty level actually work two or three jobs and still cannot make ends meet. Now suppose, "just to play devil's advocate," someone else says it is a well-known fact that poor people have babies on purpose, so they can receive welfare benefits. That assimilates the resistance by sending the conversation off into a discussion of whether people should procreate if they cannot support their children, rather than engaging with the counterstory about the working poor. The devil's advocate technique can also be used to counter counterstories that display the sexism behind the wage gap. When this comes up there is usually someone — not always a man — who, just for the sake of argument, says that women are paid less because they choose to take time off from work to care for their children or elderly relatives. It's a theory. For the sake of argument. Here, as in the case of cutbacks for the poor, the master narratives purporting to justify the oppression absorb the counterstory by wrapping it in a related master narrative for which the teller takes no responsibility. Often, people who play devil's 
advocate actually believe the arguments they say they are making just for fun, but because they suspect that the arguments would make them sound arrogant or privileged, they put them in the devil's mouth.

These discussions may feel like fun to the devil's advocate, but that is because the issues under discussion do not directly affect them. If they are not one of the working poor their motives for having children are not questioned, and if they are a man they are not expected, in any case, to cut back their hours at work to take care of the children. But there may well be people present in these conversations who do not think devil's advocacy is fun at all. As a blogger on Feministing puts it:

It is physically and emotionally draining to be called upon to prove that these systems of power exist. For many of us, just struggling against them is enough-now you want us to break them down for you? Imagine having weights tied to your feet and a gag around your mouth, and then being asked to explain why you think you are at an unfair disadvantage. Imagine watching a video where a young man promises to kill women who chose not to sleep with him and then being forced to engage with the idea that maybe you are just a hysterical feminist seeing misogyny where there is none. It is incredibly painful to feel that in order for you to care about my safety, I have to win this verbal contest you have constructed "for fun."

\subsection{Play What about Me?}

A third way to counter a counterstory is to deflect the conversation back to the dominant group. Since the 1990 os a loose coalition calling themselves Men's Rights Activists have been countering feminist counterstories by insisting that it is men who are oppressed and women the oppressors. Men's rights groups have identified women as the source of emasculation and subjugation, claiming that they file false paternity suits and maliciously accuse innocent men of raping them. Also, some women make more money than some men do. (The eyebrow shoots skyward.) Paul Elam, founder of A Voice for Men, has declared publicly that if he ever sits on the jury of a rape trial, he will vote to acquit even in the face of overwhelming evidence that the defendant is guilty. Why? Because the legal system "is patently untrustworthy when it comes to the offense of rape.... In this, the age of misandry, not one aspect of a rape case can be trusted.... The accuser cannot be trusted." ${ }^{6}$ Now, Elam's way of countering the counterstory by turning the focus back on the poor, mistreated men is not particularly good because it is

5 Britto Schwartz, "An Open Letter to Privileged People Who Play Devil's Advocate."

6 Ford, “A Lesson for Men's Rights Activists on Oppression,” 14. 
too crude to be plausible, but it does display how the mechanism works: let us not talk about you when we could be talking about the much more important and put-upon Me.

That example is pretty blatant, so let us look at one that is more subtle. I refer to the mothers of young men accused of rape, who defend their sons vigorously with the claim that they could not possibly have done it-it was not in their character. This looks altruistic, but often it is really a variant on "What about Me?" because what they are actually saying is, "Look at all I've done for him. I'm not the kind of mother who would have a rapist for a son."

Another example of the "What about Me?" technique has been described by the philosopher Uma Narayan. Since at least the publication in 1978 of Edward Said's Orientalism, many counterstories have been launched against colonialist master narratives of the barbarism and backwardness of the brown-skinned people living in the Near East and on the Indian subcontinent. But Narayan reports that in their eagerness to distance themselves from Western imperialism, Western feminists are unwilling to say anything negative about Eastern cultures. And they are equally unwilling to hear Narayan's criticisms of the Indian social order. As a result, in their conversations with her, they keep pulling the conversation back to how Western colonialism is responsible for all of India's ills.

What starts as a proper stress upon negative Western attitudes and interferences in the Third World grows into a focus on the Big Bad West, one that operates so as to virtually eclipse the Third World and its agents, institutions, and responses from view. The Third World virtually vanishes, except as a flat backdrop or frame for the Bad Deeds of the West. I have often felt like Alice, watching "the Third World" slowly disappearing from view until it has all the substantiality of the Cheshire Cat's grin. ${ }^{7}$

This sort of breast-beating is not confined to groups with a colonialist history, of course. It also manifests itself as white liberal guilt, which is far more interested in how bad I feel about racism than in what it is like for you to be oppressed by it.

\subsection{Require Victims to Be Blameless}

The fourth way to counter a counterstory is a specific kind of victim blaming, which says that a victim of oppression is a victim, all right, but only if she is of sterling moral character. Did he get angry when your friend told that anti-Semitic joke? Well, everybody knows these Jews do not have a sense of humor. Was her skirt too short or her history of sexual activity too long? Then it was not really rape or, at least, she was asking for it. Had he ever been accused of petty

7 Narayan, Dislocating Cultures, 140. 
theft? Then even though he was not armed, you cannot really blame the police for gunning him down and leaving his body on the road for four hours.

In the United States it is not uncommon to hear Zionists defend Israel's oppression of Palestinians by pointing out that Hamas is a terrorist organization, as if that justifies the oppression. While Hamas's activities certainly make it harder to end the violence in that part of the Middle East, the assumption that oppression is somehow legitimate because not everybody in the oppressed group is of upright moral character can just as certainly be questioned.

\subsection{Change the Subject}

When all else fails, a master narrative can absorb a counterstory by changing the subject. When women complain about sexual harassment in the workplace, for instance, the conversation frequently veers off in the direction of the woman's work performance or her attitude toward her bosses. The same thing can happen when someone tries to start a discussion protesting some racist incident or pattern of incidents. Often the conversation morphs into a discussion about all the ways in which society is now "post-racial," or why it is racist to bring up the topic of race in the first place. What gets lost sight of in these conversations is the oppressive practice or incident that was the initial reason for the discussion.

\section{HOW TO SLAY A DRAGON}

By now you are probably wondering why, if master narratives are so good at repelling or assimilating them, anyone would bother to launch a counterstory at all. If I am right about any of this - and mind you, what I have provided is not even close to an exhaustive list of the ways to counter a counterstory-then it seems as if Bilbo the hobbit's hope of defeating the gargantuan Smaug who absorbs all the dwarfs' treasure is doomed from the outset. So I am going to end this paper by explaining why that simply is not so.

To see that it is not, we have only to look at a counterstory that has been quite effective in getting uptake by the oppressors, to the point where many members of the oppressed group are now able to exercise their agency more freely in the wider society. In 2006, Tarana Burke founded the \#MeToo movement to help survivors of sexual violence, particularly young women of color from poor communities, speak out in public about what had happened to them and find resources for healing. The movement was aimed at destigmatizing survivors by highlighting the breadth and impact sexual violence has had on women and disrupting the systems that allow this violence to flourish. \#MeToo had already been in existence for eleven years when, on October 15, 2017, Alyssa Milano reig- 
nited it on Twitter: "If you've been sexually harassed or assaulted, write 'me too' as a reply to this tweet." Burke says it is more than a hashtag — it is the start of a public conversation and a space for community healing. Many women have now come forward under the hashtag to report their experiences with sexual harassment, molestation, and rape.

The \#MeToo movement seems to be creating a cultural shift that has made it easier to prosecute men like Bill Cosby and Harvey Weinstein, and perhaps also propelled the downfall of Judge Roy Moore. But to change the culture, the point has to be not that women are revealing abuse in the workplace, but that it occurs. Koa Beck, former editor-in-chief of the website Jezebel, urged that the takeaway should not be that men and women cannot work together, but rather that men and women step up as bystanders when they see harassment at work. The leaders of the movements are now trying to shift public focus away from the high-profile cases and onto women like Suzette Wright, who suffered in silence for years at Ford Motor Company. The shifted focus might begin to erode the culture in which gendered messages about sex, power, and courtship start young and are deeply ingrained.

The current social climate makes it easy for sexual predators not to repent. President Donald Trump and others have repeatedly expressed sympathy for Supreme Court Justice Brett Kavanaugh, who, before he was confirmed, had been accused by Christine Blasey Ford of violent attempted rape when they were teenagers. "I feel so badly for him. This is not a man who deserves this," Trump said. Kate Manne calls this kind of concern himpathy-"the inappropriate and disproportionate sympathy powerful men often enjoy in cases of sexual assault, intimate partner violence, homicide and other misogynistic behavior." Himpathy is on display everywhere: in the actions of a former editor of the New York Review of Books who published a self-indulgent essay by a disgraced Canadian talk-show host accused of sexual harassment by many women; in Senator Lindsay Graham's outraged indignation at how Kavanaugh was treated; in the "boys will be boys" attitude visible all over Facebook and Twitter. All this focuses exclusively on the perpetrator's pain, the perpetrator's future, the tarnishing of the perpetrator's good name. And the higher the perpetrator stands in the social hierarchy, the more himpathy he attracts, so the bulk of social concern, care, respect, and attention goes to the most privileged men in our society. Himpathy goes a long way to explain why women who have been harassed or assaulted are not believed. The warm feelings all go to the male perpetrator: he was just a boy, the rules were different then, she is trying to get him into trouble. Because 
himpathy is such a powerful moral emotion, it has to be consciously recognized and strenuously resisted.

If that is so, why do I see hope in the \#MeToo counterstory? Kavanaugh was appointed to the Supreme Court in spite of it, but the movement has accomplished one thing: in the heated discussions surrounding his confirmation, almost no one attacked Blasey's character. No one said she was a scheming slut, or deserved what she got because she had been drinking. Instead, those who disbelieved her speculated that she had misidentified her assailant, or made too much out of an incident that happened long ago. That may not seem like much, but it is evidence that, despite the master narrative's attempts to absorb it, the counterstory is getting uptake.

The reason why any counterstory has a chance of succeeding, despite whatever defenses a master narrative might set up against it, is that oppressive master narratives are always false. That means there are always cracks in the story, soft spots in Smaug's underbelly that let the arrow find its mark. It is stories like Mann's that show us the master narrative's mechanism, that ultimately bring the narrative down. If you shoot enough counterstories at any master narrative, you will find that it is not so invincible after all.

One story alone will not do it, of course. Nor will even a raft of stories. But if you loose enough counterstories at that soft spot on Smaug's underbelly where one of his scales fell off, you will discover that he is not so invincible after all.

Michigan State University

hlinde@msu.edu

\section{REFERENCES}

Britto Schwartz, Juliana. “An Open Letter to Privileged People Who Play Devil's Advocate." Feministing, May 30, 2014. http://feministing.com/2014/o5/30/ an-open-letter-to-privileged-people-who-play-devils-advocate.

Ford, Clementine. "A Lesson for Men's Rights Activists on Oppression." The Drum, June 19, 2014. http://www.abc.net.au/news/2014-o6-19/ford-a-lesson -for-mens-rights-activists-on-real-oppression/5533412.

Lindemann, Hilde. Damaged Identities, Narrative Repair. Ithaca, NY: Cornell University Press, 2001.

- Holding and Letting Go: The Social Practice of Personal Identities. New York: Oxford University Press, 2014. 
Manne, Kate. "Brett Kavanaugh and America’s 'Himpathy' Reckoning." New York Times, September 26, 2018.

Narayan, Uma. Dislocating Cultures: Identities, Traditions, and Third World Feminism. New York: Routledge, 1998.

National Public Radio. "ProPublica Analyzes 3 Decades of Deadly Police Shootings," October 14, 2014. https://www.npr.org/2014/10/14/356045089/ propublica-analyzes-data-on-male-victims-of-deadly-police-shootings.

Said, Edward. Orientalism. London: Routledge and Kegan Paul, 1978.

Sikora, Andrew G., and Michael Mulvihill. "Trends in Mortality Due to Legal Intervention in the United States, 1979 through 1997." American Journal of Public Health 92, no. 5 (May 2002): 841-43. 